See discussions, stats, and author profiles for this publication at: https://www.researchgate.net/publication/332153763

\title{
Medical treatment of urinary incontinence in the bitch
}

Article in Vlaams Diergeneeskundig Tijdschrift · January 2019

CITATIONS

0

4 authors:

8

Joep Timmermans

Vets Now Referrals limited

1 PUBLICATION OCITATIONS

SEE PROFILE

Hilde de Rooster

Ghent University

210 PUBLICATIONS 1,020 CITATIONS

SEE PROFILE

Some of the authors of this publication are also working on these related projects:

Rupture of cruciate ligaments in dogs View project

Combretastatin A4-Phosphate in canine cancer patients View project
READS

223

Bart Van Goethem

Ghent University

73 PUBLICATIONS 314 CITATIONS

SEE PROFILE

Dominique Paepe

Ghent University

96 PUBLICATIONS 393 CITATIONS

SEE PROFILE 


\title{
Medical treatment of urinary incontinence in the bitch
}

\author{
Medicamenteuze behandeling van urinaire incontinentie bij de teef
}

\author{
J. Timmermans, B. Van Goethem, H. de Rooster, D. Paepe
}

Small Animal Department, Faculty of Veterinary Medicine, Ghent University, Salisburylaan 133, 9820 Merelbeke, Belgium

bart.vangoethem@ugent.be

\begin{abstract}
$A_{\text {bstract }}$
Urinary incontinence, an uncontrolled urine leakage during the storage phase of micturition, is a common condition in female dogs. In intact bitches, the reported prevalence is only $0.2-0.3 \%$, but in spayed bitches it varies between 3.1-20.1\%. Most commonly, dogs with acquired urinary incontinence suffer from urethral sphincter mechanism incompetence. This condition seems to be multifactorial, and although the exact pathophysiology remains unclear, potential risk factors include gender, gonadectomy, breed, body weight, urethral length and bladder neck position. In daily practice, the diagnosis of urethral sphincter mechanism incompetence is usually made after eliminating other potential causes of urinary incontinence. Incontinent bitches are primarily treated with medications, such as alpha-adrenergic drugs, e.g. phenylpropanolamine and oestrogens. Surgery is recommended when patients become refractory to medical treatment.
\end{abstract}

\section{SAMENVATTING}

Urinaire incontinentie, het ongecontroleerd verlies van urine tijdens de vullingsfase van het urineren, is een veelvoorkomende aandoening bij vrouwelijke honden. De gerapporteerde prevalentie bij intacte teven is slechts $0,2-0,3 \%$, maar dit varieert tussen de 3,1-20,1\% bij gesteriliseerde teven. Honden met verworven urine-incontinentie lijden meestal aan urethrale sfinctermechanisme-incompetentie. Deze aandoening lijkt door meerdere factoren veroorzaakt te worden en, alhoewel de exacte pathofysiologie niet volledig bekend is, zijn potentiële risicofactoren geslacht, gonadectomie, ras, lichaamsgewicht, urethrale lengte en positie van de blaashals. In de praktijk is de diagnose van urethrale sfinctermechanisme-incompetentie doorgaans gebaseerd op uitsluiting van andere potentiële oorzaken van urine-incontinentie. Incontinente teven worden hoofdzakelijk medicamenteus behandeld met onder andere alfa-adrenerge geneesmiddelen, bijvoorbeeld fenylpropanolamine en oestrogenen. Chirurgie is aangeraden als de patiënt refractair wordt ten opzichte van de medicamenteuze behandeling.

\section{INTRODUCTION}

Normal micturition in dogs is composed of a complex interaction between the storage of urine in the bladder and emptying of the bladder (Fischer and Lane, 2011; Byron, 2015). Urinary incontinence (UI) is defined as an uncontrolled leakage during the storage phase (Abrams et al., 2003). This can be categorized in two main groups: neurogenic or non-neurogenic induced UI, of which, in dogs, the latter can either occur congenitally or acquired (Applegate et al., 2018) (Table 1).

The prevalence of UI in intact bitches is as low as $0.2-0.3 \%$ (Holt and Thrusfield, 1993). In spayed bitch- es, this prevalence has historically been reported up to $20.1 \%$ (Arnold et al., 1989), but in more recent studies by Forsee et al. (2013) and O'Neill et al. (2017), numbers closer to 3-5\% have been reported.

In this review, the most common cause of UI, the diagnostic procedure and medical treatment options are highlighted.

\section{ANATOMY}

The lower urinary tract consists of the bladder, comprised of an apex, body and bladder neck, and the urethra, containing the external urethral sphinc- 
Table 1. Main differential diagnoses of urinary incontinence. Adapted from: Fischer and Lane (2017).

\begin{tabular}{ll}
\hline & Urinary incontinence \\
\hline Neurogenic & Non-neurogenic \\
\hline - Lower motor neuron disorders & $\bullet$ Urethral sphincter mechanism incompetence (USMI) \\
- Upper motor neuron disorders & - Congenital disorders \\
- Detrusor urethral dyssynergia & - Detrusor hyperreflexia \\
- Dysautonomia & Anatomical or functional urethral obstruction \\
- Primary bladder atony & - Bladder atony due to muscle weakness or medications \\
\hline
\end{tabular}

ter (Fischer and Lane, 2011). The external urethral sphincter could also be described as part of the sphincter mechanism and not as a separate structure. Micturition is coordinated through sympathetic, parasympathetic and somatic innervation, combined with actions regulated from central control centers (DiBartola and Westropp, 2014) (Figure 1). The sympathetic hypogastric nerve, originating from spinal segment L1-L4, is mainly important during the storage phase because norepinephrine release during nerve stimulation results in detrusor relaxation, filling of the urinary bladder and prevention of subsequent urinary leakage (Fischer and Lane, 2011; DiBartola and Westropp, 2014; Byron, 2015). This is accomplished through activation of beta-receptors in the bladder and alpha1 -adrenergic receptors in the smooth muscle within the urethral sphincter mechanism (DiBartola and Westropp, 2014). The pelvic nerve, which originates from spinal segment S1-S3, supplies parasympathetic innervation (Fischer and Lane, 2011). It ensures excitatory input to the bladder (bladder contraction) and inhibitory input to the urethra (urethral relaxation), resulting in urination (DiBartola and Westropp, 2014).
Lastly, the pudendal nerve also originates from spinal segment S1-S3, supplies somatic innervation and stimulates the external urethral sphincter (Fischer and Lane, 2011; DiBartola and Westropp, 2014).

\section{URETHRAL SPHINCTER MECHANISM IN- COMPETENCE}

Dogs with acquired UI most commonly suffer from urethral sphincter mechanism incompetence (USMI) (Byron et al., 2017). The pathophysiology of USMI remains incompletely elucidated. Most likely, this condition is multifactorial, resulting from hormonal, as well as structural and functional changes (Applegate et al., 2018). Several risk factors have been described for the development of USMI.

\section{Gender}

USMI can develop in both male and female dogs, but the condition is rare in males with a reported risk of up to $1 \%$ (Holt, 1990; Reichler and Hubler,

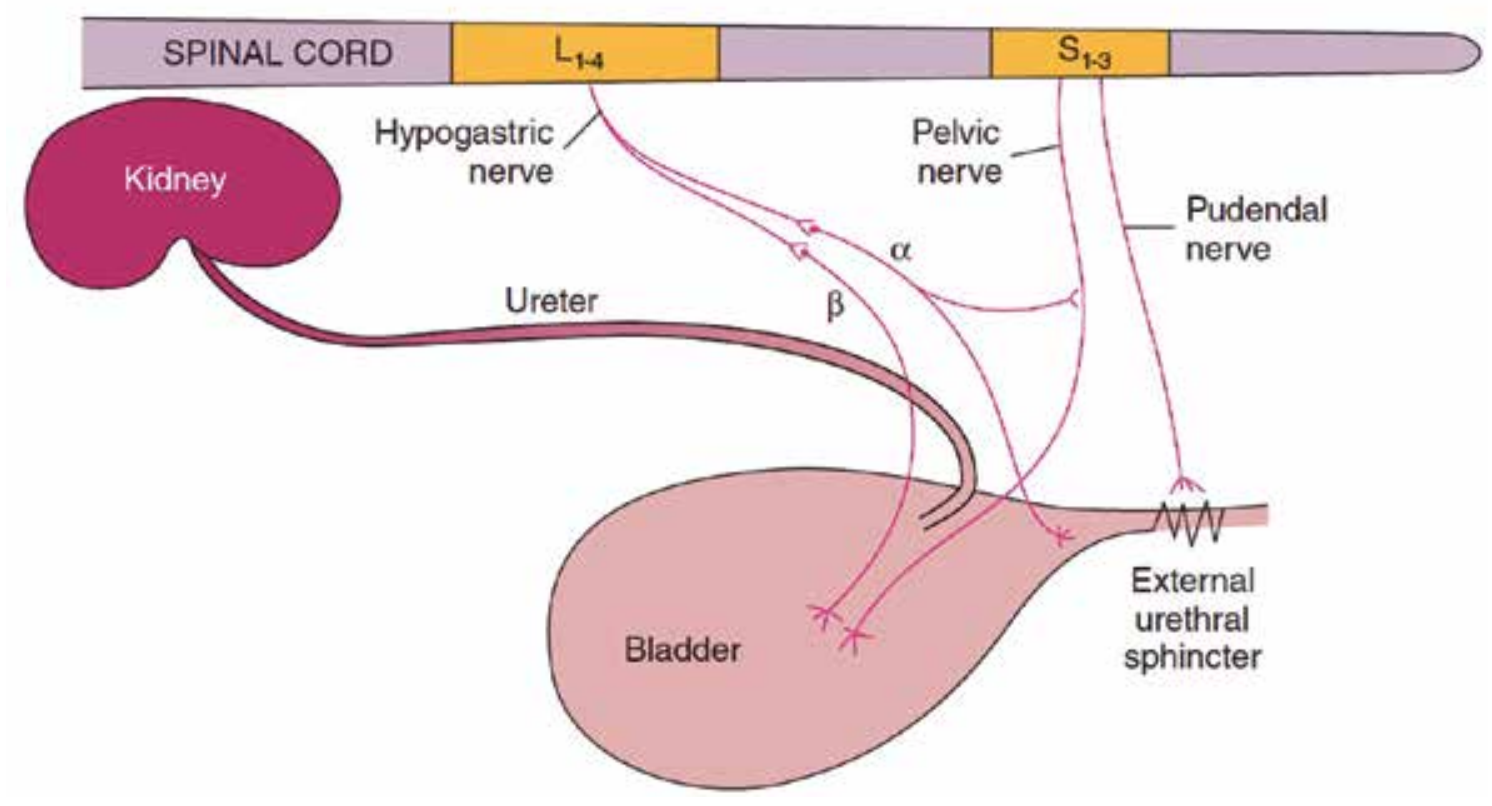

Figure 1. Simplified representation of the innervation of the lower urinary tract. Adapted from: DiBartola and Westropp (2014). 
2014). Extensive studies have been conducted in bitches to support the prevalence, which is not the case in males (Aaron et al., 1996; Forsee et al., 2013).

\section{Gonadectomy}

Spaying in dogs increases the risk of USMI (Holt and Thrusfield, 1993; Thrusfield et al., 1998; Reichler and Hubler, 2014). According to Holt (1985), approximately $90 \%$ of dogs with USMI have a history of prior gonadectomy. In about $75 \%$ of the bitches, the onset of UI occurs within three years after gonadectomy, but it is not uncommon that clinical signs occur directly after the surgery or as late as ten years after (Arnold et al., 1989; Reichler and Hubler, 2014).

So far, no consensus has been reached about the link between the age of the dog at spaying and the concurrent risk of USMI (Arnold et al., 1989; Arnold, 1997; Thrusfield et al., 1998; Stöcklin-Gautschi et al., 2001; de Bleser et al., 2011; Beauvais et al., 2012; Forsee et al., 2013; Reichler and Hubler, 2014). In earlier studies, an increased risk of developing incontinence has been mentioned when spaying was performed before three months of age (Thrusfield et al., 1998; Stöcklin-Gautschi et al., 2001), or when dogs have had their first oestrus (Arnold et al., 1989). On the other hand, in more recent publications, no evidence to support a relationship between age at which gonadectomy is performed and the development of USMI in bitches has been found (de Bleser et al., 2011; Beauvais et al., 2012; Forsee et al., 2013).

The suggestion has been made that the severity of UI might be different depending on the age the animal was spayed (Reichler and Hubler, 2014). In a study by Arnold (1997), it was shown that gonadectomy before puberty resulted in UI after an increased abdominal pressure, as expected, but also during walks or when the animal was awake. Dogs neutered after puberty are mainly dribbling when recumbent with less intensity (Stöcklin-Gautschi et al., 2001).

Recently, Byron et al. (2017) described a relationship between gonadectomy and body weight, which will be discussed below.

The extent of surgery, ovariectomy versus ovariohysterectomy, does not result in different continence rates (Van Goethem et al., 2006). Likewise, the incidence of USMI is not different in dogs with elective versus emergency procedure (Forsee et al., 2013).

\section{Breed and body weight}

Urinary incontinence is more common in medium to large-breed dogs (de Bleser et al., 2011). Previous studies have demonstrated that dogs weighing more than $10 \mathrm{~kg}$ have a 3.7-times higher risk of developing USMI than smaller dogs (de Bleser et al., 2011), and dogs weighing more than $15 \mathrm{~kg}$ have a 7.2-times higher risk (Forsee et al., 2013). Additionally, Byron et al. (2017) found a relationship between age at the time of ovariohysterectomy and body weight in developing USMI. According to this study, the risk of developing USMI for dogs with an expected adult weight of more than $25 \mathrm{~kg}$ decreases for every month gonadectomy is postponed during their first year. In the same study, dogs weighing less than $15 \mathrm{~kg}$ were reported not to be susceptible to this risk, making it reasonable to spay these dogs prior to the first heat to reduce the risk of unwanted pregnancy or developing mammary neoplasia and pyometra (Byron et al., 2017). Some breeds are clearly overrepresented in the literature and have an increased risk of USMI, such as Doberman pinscher, Old English sheepdog, Springer spaniel, boxer, rottweiler, Weimaraner, Giant schnauzer and Irish setter (White, 2001; Reichler and Hubler, 2014). Based on an investigation in 928 entire or neutered male and female Dobermans, a prevalence of $15.8 \%$ was found (Mandigers et al., 2006). Nevertheless, developing USMI is not restricted to these breeds; all breeds can be affected.

\section{Urethral length and bladder neck position}

Holt (1985c) documented that incontinent bitches are more likely to present with intrapelvic bladder neck than continent bitches that usually have intraabdominal bladder neck (Holt, 1985b). Radiographically, spayed bitches also tend to have a shorter urethra than intact bitches, although it is unknown how decisive these radiographic findings are in the occurrence of UI (Holt, 1985c; Wang et al., 2006).

\section{DIAGNOSIS}

Diagnosing USMI may be challenging and typically relies on elimination of other potential causes of UI (Applegate et al., 2018) (Table 1). Congenital conditions, e.g. ectopic ureter and patent urachus, must be evaluated in case an animal is incontinent since birth or at least before spaying (Byron, 2015). Affected dogs may present with either intermittent or continuous UI (Holt, 1985c), and observing micturition increases the chance of correct diagnosis (Byron, 2015). It is important to monitor for conscious or unconscious urination, stranguria and to palpate the bladder afterwards for residual volume (Byron, 2015). Findings on general physical examination are unfortunately not specific for the presence of USMI (Applegate et al., 2018). Neurological examination is indicated with particular interest for the urogenital system to evaluate the perineal reflex (pudendal nerve), as well as a vaginal and rectal examination to diagnose anatomical abnormalities (Labato, 2018).

Additional diagnostic procedures are necessary to diagnose USMI (Applegate et al., 2018). The ideal diagnostic work-up to support the presumptive diagnosis of USMI includes a complete blood count, biochemistry panel, urinalysis (including urine specific 
gravity and urine culture), abdominal radiographs and abdominal ultrasound. Although most of these diagnostics are within normal limits when USMI is present in a dog, these tests should be performed to rule out concurrent diseases (Applegate et al., 2018). Performing abdominal radiographs and/or ultrasound allows excluding the presence of urinary calculi and neoplasia including possible metastatic disease. Urodynamic studies should be performed to make the definitive diagnosis of USMI (Applegate et al., 2018). When a minimum database is obtained but the specialized equipment for urodynamic studies is not available, it is acceptable to start empirical treatment and confirm the diagnosis of USMI as a result of treatment success (Applegate et al., 2018). However, diagnostics should be repeated in case of a recurrence of UI (Reichler and Hubler, 2014).

\section{MEDICAL TREATMENT}

Medical management is always the first treatment option because it is not invasive and successful in up to $97 \%$ of cases (Applegate et al., 2018). Alphaadrenergic drugs are the preferred initial treatment in dogs with USMI (Richter and Ling, 1985; Applegate et al., 2018). It is important to know the potential side effects and contraindications of the medications described below to decide on the best choice of drugs and alter treatment accordingly.

\section{Alpha-adrenergic drugs}

Phenylpropanolamine, a sympathomimetic alphaadrenergic drug, increases urethral sphincter tone by tensioning smooth muscles in both the bladder neck and urethra (Richter and Ling, 1985; Scott et al., 2002; Applegate et al., 2018). The reported efficacy of this drug varies between $86-97 \%$ (Scott et al., 2002; Claeys et al., 2011). One $\mathrm{mg} / \mathrm{kg}$ body weight is administered two to three times a day (Scott et al., 2002), or alternatively $1.5 \mathrm{mg} / \mathrm{kg}$ body weight can be administered once daily (Claeys et al., 2011). Improvement should be noticed within three to four weeks after starting treatment (Applegate et al., 2018). Side effects of phenylpropanolamine include anxiety, excitement and aggression, which may result in an increased sympathetic tone (Burgherr et al., 2007). Other alpha-adrenergic drugs, such as ephedrine or pseudoephedrine, illustrate more adverse effects, e.g. panting, hyporexia and lethargy, result in lower urethral closure pressure and have a lower efficacy of 25$75 \%$ only (Byron et al., 2007; Applegate et al., 2018). Phenylpropanolamine or other alpha-adrenergic drugs are contraindicated when hypertension could have disastrous consequences, e.g. in heart and kidney disease or glaucoma (Burgherr et al., 2007).

The effect of alpha-adrenergic drugs decreases over time (Richter and Ling, 1985; White and Pomeroy, 1989; Reichler and Hubler, 2014). Unfortunately, there is no cut-off period available from previously published studies as to when to expect decreased effect of medications or refractory incontinence.

\section{Oestrogens}

Estriol, a short-acting oestrogen, increases urethral closure pressure by stimulating urethral mucosal tissue (Mandigers and Nell, 2001). The reported efficacy is 65-83\% (Arnold, 1997; Mandigers and Nell, 2001). A dose of $2 \mathrm{mg}$, irrespective of the dog's bodyweight, is administered orally once daily for the first seven to fourteen days (Byron, 2018). Clinical improvement may be expected within this time frame (Mandigers and Nell, 2001). The recommended dose is reduced after improvement by $0.5 \mathrm{mg}$ per week until the minimum effective dose is reached, which can be continued every other day (Mandigers and Nell, 2001; Fischer and Lane, 2017). If no response to treatment is achieved after the first two weeks, it may be beneficial to continue dosing $2 \mathrm{mg} / \mathrm{dog}$ until clinical improvement is appreciated (Mandigers and Nell, 2001). Potential adverse effects include vulvar hyperplasia, vaginal discharge, attractiveness to males and pyometra in entire and ovariectomized bitches (Byron et al., 2007; Schotanus et al., 2008; Applegate et al., 2018). Alternatively, diethylstilbestrol can be administered, which is a long-acting oestrogen. However, this could induce more adverse effects than estriol, such as myelosuppression (Hoeijmakers et al., 2003; Sontas et al., 2009).

\section{Multidrug therapy}

When monotherapy does not provide satisfactory results, multidrug therapy may be initiated (Aaron et al., 1996; Reichler et al., 2003). For example, combining alpha-adrenergic drugs with oestrogens would theoretically result in a synergistic effect because of their different mechanism of action (Aaron et al., 1996; Applegate et al., 2018). No recommendations have been published regarding altered dosing schedules or the consequences of this drug combination protocol on potential side effects. Hamaide et al. (2006) used the doses described above for phenylpropanolamine and estriol to investigate urodynamic and morphologic changes, but multidrug therapy did not appear beneficial compared to monotherapy.

Reichler et al. (2003) described a combination therapy of gonadotropin-releasing hormone $(\mathrm{GnRH})$ analogues and phenylpropanolamine $1.5 \mathrm{mg} / \mathrm{kg}$ three times a day in dogs. Leuprolide, deslorelin and buserelin, examples of GnRH analogues, are injected subcutaneously and result in a suppression of follicle stimulating hormone and luteinizing hormone. The doses used include $11.25 \mathrm{mg}, 5-10 \mathrm{mg}$, and $6.3 \mathrm{mg}$, respectively. These formulations are effective between one to six months (Reichler et al., 2003). Although the consequences to the urethral sphincter tone are incompletely elucidated, these $\mathrm{GnRH}$ analogues seem 
to have temporary positive effects in almost $50 \%$ of dogs with USMI (Reichler et al., 2003, 2006). Longterm results of GnRH solo treatment are disappointing, with only a few dogs still continent after a mean of 247 days even after repeated injections. So far, no side effects of this treatment have been mentioned (Reichler et al., 2003).

\section{Refractory patients}

Refractory patients are dogs that do not respond or tolerate medical treatment, or initially respond to medications and ultimately show clinical symptoms suggestive for USMI. It has been reported that up to $56 \%$ of dogs develop refractory incontinence (Currao et al., 2013). Treatment options for these patients include surgical treatment, such as urethral bulking, colposuspension, urethropexy and an artificial urethral sphincter (Applegate et al., 2018).

\section{CONCLUSION}

Approximately 3-5\% of spayed bitches are affected with UI. USMI is the most common cause of acquired UI in spayed bitches and the frequency is influenced by gender, breed, body weight, gonadectomy, urethral length and bladder neck position. Diagnosing USMI is usually based on excluding other causes of incontinence and can be confirmed after performing urodynamic studies. USMI is primarily treated with medications, such as phenylpropanolamine and estriol, of which the former is the treatment of choice. Additional scientific research and a longer follow-up period are required to further investigate what causes refractory incontinence, the benefits of multidrug therapy including the dosing schedules required in practice, and when refractory incontinence is likely to occur. Surgery is recommended when bitches become refractory to medical treatment of UI.

\section{REFERENCES}

Aaron, A., Eggleton, K., Power, C., Holt, P.E. (1996). Urethral sphincter mechanism incompetence in male dogs: a retrospective analysis of 54 cases. Veterinary Record 139, 542-546.

Abrams, P., Cardozo, L., Fall, M., Griffiths, D., Rosier, P., Ulmsten, U., Van Kerrebroeck, P., Victor, A., Wein, A. (2003). The standardisation of terminology in lower urinary tract function: Report from the standardisation sub-committee of the International Continence Society. Urology 61, 37-49.

Applegate, R., Olin, S., Sabatino, B. (2018). Urethral sphincter mechanism incompetence in dogs: an update. Journal of the American Animal Hospital Association 54, 22-29.

Arnold, S. (1997). Urinary incontinence in castrated bitches. 2. Diagnosis and treatment. Schweizer Archiv für Tierheilkunde 139, 319-324.
Arnold, S., Arnold, P., Hubler, M., Casal, M., Rüsch, P. (1989). Urinary incontinence in spayed female dogs: frequency and breed disposition. Schweizer Archiv für Tierheilkunde 131, 259-263.

Beauvais, W., Cardwell, J.M., Brodbelt, D.C. (2012). The effect of neutering on the risk of urinary incontinence in bitches - a systematic review. Journal of Small Animal Practice 53, 198-204.

Burgherr, T., Reichler, I., Hung, L., Hubler, M., Arnold, S. (2007). Efficacy, tolerance and acceptability of Incontex in spayed bitches with urinary incontinence. Schweizer Archiv für Tierheilkunde 149, 307-313.

Byron, J.K. (2015). Micturition disorders. Veterinary Clinics of North America - Small Animal Practice 45, 769782

Byron, J.K. (2018). Diseases of Abnormal Micturition, in: Ettinger, S.J., Feldman, E.C., Côté, E. (editors), Textbook of Veterinary Internal Medicine: Diseases of the Dog and the Cat. Eighth edition, Elsevier, St. Louis, Missouri, USA, p. 4852.

Byron, J.K., March, P.A., Chew, D.J., DiBartola, S.P. (2007). Effect of phenylpropanolamine and pseudoephedrine on the urethral pressure profile and continence scores of incontinent female dogs. Journal of Veterinary Internal Medicine 21, 47-53.

Byron, J.K., Taylor, K.H., Phillips, G.S., Stahl, M.S. (2017). Urethral sphincter mechanism incompetence in 163 neutered female dogs: diagnosis, treatment, and relationship of weight and age at neuter to development of disease. Journal of Veterinary Internal Medicine 31, 442-448.

Claeys, S., Rustichelli, F., Noël, S., Hamaide, A. (2011). Clinical evaluation of a single daily dose of phenylpropanolamine in the treatment of urethral sphincter mechanism incompetence in the bitch. Canadian Veterinary Journal 52, 501-505.

Currao, R.L., Berent, A.C., Weisse, C., Fox, P. (2013). Use of a percutaneously controlled urethral hydraulic occluder for treatment of refractory urinary incontinence in 18 female dogs. Veterinary Surgery 42, 440-447.

de Bleser, B., Brodbelt, D.C., Gregory, N.G., Martinez, T.A. (2011). The association between acquired urinary sphincter mechanism incompetence in bitches and early spaying: A case-control study. Veterinary Journal 187, 42-47.

DiBartola, S.P., Westropp, J.L. (2014). Disorders of micturition. In: Nelson, R.W., Couto, C.G. (editors), Small Animal Internal Medicine. Fifth edition, Elsevier, St. Louis, Missouri, USA, p. 704-705.

Fischer, J., Lane, I.F. (2011). Micturition disorders, in: Bartges, J., Polzin, D.J. (editors), Nephrology and Urology of Small Animals. Wiley-Blackwell, Ames, Iowa, USA, p. 755-756.

Fischer, J., Lane, I.F. (2017). Urinary incontinence and urine retention, in: Elliott, J., Grauer, G.F., Westropp, J.L. (editors). BSAVA Manual of Canine and Feline Nephrology and Urology. Third edition, British Small Animal Veterinary Association, Gloucester, UK, p. 24-36.

Forsee, K.M., Davis, G.J., Mouat, E.E., Salmeri, K.R., Bastian, R.P. (2013). Evaluation of the prevalence of urinary incontinence in spayed female dogs: 566 cases (20032008). Journal of the American Veterinary Medical Association 242, 959-962.

Hamaide, A.J., Grand, J.G., Farnir, F., Le Couls, G., Snaps, F.R., Balligand, M.H., Verstegen, J.P. (2006). Urodynamic and morphologic changes in the lower portion of 
the urogenital tract after administration of estriol alone and in combination with phenylpropanolamine in sexually intact and spayed female dogs. American Journal of Veterinary Research 67, 901-908.

Hoeijmakers, M., Janszen, B., Coert, A., Horspool, L. (2003). Pharmacokinetics of oestriol after repeated oral administration to dogs. Research in Veterinary Science $75,55-59$.

Holt, P.E. (1985a). Urinary incontinence in the bitch due to sphincter mechanism incompetence: surgical treatment. Journal of Small Animal Practice 26, 237-246.

Holt, P.E. (1985b). Importance of urethral length, bladder neck position and vestibulovaginal stenosis in sphincter mechanism incompetence in the incontinent bitch. Research in Veterinary Science 39, 364-372.

Holt, P.E. (1985c). Urinary incontinence in the bitch due to sphincter mechanism incompetence: prevalence in referred dogs and retrospective analysis of sixty cases. Journal of Small Animal Practice 26, 181-190.

Holt, P.E. (1990). Urinary incontinence in dogs and cats. Veterinary Record 127, 347-350.

Holt, P.E., Thrusfield, M. V. (1993). Association in bitches between breed, size, neutering and docking, and acquired urinary incontinence due to incompetence of the urethral sphincter mechanism. Veterinary Record 133, 177-180.

Labato, M.A. (2018). Pollakiuria, stranguria, and urinary incontinence. In: Ettinger, S.J., Feldman, E.C., Côté, E. (editors), Textbook of Veterinary Internal Medicine: diseases of the dog and the cat. Eighth edition, Elsevier, St. Louis, Missouri, USA, p. 670.

Mandigers, P.J., Senders, T., Rothuizen, J. (2006). Morbidity and mortality in 928 Dobermanns born in the Netherlands between 1993 and 1999. Veterinary Record 158, 226-229.

Mandigers, R.J., Nell, T. (2001). Treatment of bitches with acquired urinary incontinence with oestriol. Veterinary Record 149, 764-767.

O’Neill, D.G., Riddell, A., Church, D.B., Owen, L., Brodbelt, D.C., Hall, J.L. (2017). Urinary incontinence in bitches under primary veterinary care in England: prevalence and risk factors. Journal of Small Animal Practice 58, 685-693.

Reichler, I.M., Hubler, M. (2014). Urinary incontinence in the bitch: an update. Reproduction in Domestic Animals $49,75-80$.

Reichler, I.M., Hubler, M., Jöchle, W., Trigg, T.E., Piché, C.A., Arnold, S. (2003). The effect of GnRH analogs on urinary incontinence after ablation of the ovaries in dogs. Theriogenology 60, 1207-1216.
Reichler, I.M., Jöchle, W., Piché, C.A., Roos, M., Arnold, S. (2006). Effect of a long acting GnRH analogue or placebo on plasma $\mathrm{LH} / \mathrm{FSH}$, urethral pressure profiles and clinical signs of urinary incontinence due to Sphincter mechanism incompetence in bitches. Theriogenology 66, 1227-1236.

Richter, K.P., Ling, G. V. (1985). Clinical response and urethral pressure profile changes after phenylpropanolamine in dogs with primary sphincter incompetence. Journal of the American Veterinary Medical Association 187, 605-611.

Schotanus, B.A., De Gier, J., Van Der Lugt, J.J., Okkens, A.C. (2008). Estriolum treatment in the bitch: A risk for uterine infection? Reproduction in Domestic Animals 43, 176-180.

Scott, L., Leddy, M., Bernay, F., Davot, J.L. (2002). Evaluation of phenylpropanolamine in the treatment of urethral sphincter mechanism incompetence in the bitch. Journal of Small Animal Practice 43, 493-496.

Sontas, H.B., Dokuzeylu, B., Turna, O., Ekici, H. (2009). Estrogen-induced myelotoxicity in dogs: A review. The Canadian Veterinary Journal 50, 1054-1058.

Stöcklin-Gautschi, N.M., Hässig, M., Reichler, I.M., Hubler, M., Arnold, S. (2001). The relationship of urinary incontinence to early spaying in bitches. Journal of Reproduction and Fertility, Supplement 57, 233-236.

Thrusfield, M. V, Holt, P.E., Muirhead, R.H. (1998). Acquired urinary incontinence in bitches: its incidence and relationship to neutering practices. Journal of Small Animal Practice 39, 559-566.

Van Goethem, B., Schaefers-Okkens, A., Kirpensteijn, J. (2006). Making a rational choice between ovariectomy and ovariohysterectomy in the dog: A discussion of the benefits of either technique. Veterinary Surgery 35, 136143.

Wang, K.Y., Samii, V.F., Chew, D.J., McLoughlin, M.A., DiBartola, S.P., Masty, J., Lehman, A.M. (2006). Vestibular, vaginal and urethral relationships in spayed and intact normal dogs. Theriogenology 66, 726-735.

White, R.A., Pomeroy, C.J. (1989). Phenylpropanolamine: an alpha-adrenergic agent for the management of urinary incontinence in the bitch associated with urethral sphincter mechanism incompetence. Veterinary Record 125, 478-480.

White, R.N. (2001). Urethropexy for the management of urethral sphincter mechanism incompetence in the bitch. Journal of Small Animal Practice 42, 481-486. 